\title{
Latency profiles of full length HIV-1 molecular clone variants with a subtype specific promoter
}

\author{
Renée M van der Sluis, Georgios Pollakis, Marja L van Gerven, Ben Berkhout and Rienk E Jeeninga*
}

\begin{abstract}
Background: HIV-1 transcription initiation depends on cellular transcription factors that bind to promoter sequences in the Long Terminal Repeat (LTR). Each HIV-1 subtype has a specific LTR promoter configuration and even minor sequence changes in the transcription factor binding sites (TFBS) or their arrangement can impact transcriptional activity. Most latency studies have focused on HIV-1 subtype B strains, and the degree to which LTR promoter variation contributes to differences in proviral latency is therefore largely unknown. Latency differences may influence establishment and size of viral reservoirs as well as the possibility to clear the virus by therapeutic intervention.

Results: We investigated the proviral transcriptional latency properties of different HIV-1 subtypes as their LTRs have unique assemblies of transcription factor binding sites. We constructed recombinant viral genomes with the subtype-specific promoters inserted in the common backbone of the subtype B LAl isolate. The recombinant viruses are isogenic, except for the core promoter region that encodes all major TFBS, including NF $\kappa$ B and Sp1 sites. We developed and optimized an assay to investigate HIV-1 proviral latency in T cell lines. Our data show that the majority of HIV-1 infected T cells only start viral gene expression after TNF $\alpha$ activation.

Conclusions: There were no gross differences among the subtypes, both in the initial latency level and the activation response, except for subtype AE that combines an increased level of basal transcription with a reduced TNF $\alpha$ response. This subtype AE property is related to the presence of a GABP instead of NF $\kappa B$ binding site in the LTR.
\end{abstract}

\section{Background}

Combined antiretroviral therapy (cART) is able to suppress the HIV-1 plasma RNA load in patients to undetectable levels. Unfortunately, the treatment does not lead to a complete eradication of the virus from the infected individual. Even after many years of successful cART, the virus rebounds from latently integrated proviral DNA reservoirs and re-establishes systemic infection upon interruption of therapy [1-4]. HIV-1 proviral latency may be an effective means to evade the immune system, since the infected cell will go unnoticed by the immune system as long as viral antigens are not expressed and presented. The pool of latent proviruses is established early during infection and forms a steady source of proviral DNA that can last a lifetime for infected individuals [5-7]. The majority of the

\footnotetext{
* Correspondence: r.jeeninga@amc.uva.nl

Laboratory of Experimental Virology, Department of Medical Microbiology, Centre for Infection and Immunity Amsterdam (CINIMA), Academic Medical Centre, University of Amsterdam, Meibergdreef 15, 1105 AZ Amsterdam, the Netherlands
}

$\mathrm{T}$ cells, but other cellular reservoirs, such as monocytes, macrophages and dendritic cells, can also harbor latent proviruses [8-11]. HIV-1 latency remains a formidable barrier towards virus eradication as therapeutic attempts to purge these reservoirs have been unsuccessful [3,9,12,13].

Previously reported contributors to proviral latency include suppressive effects of cellular microRNAs, an impaired viral Tat-TAR axis, and epigenetic silencing via histone modification and DNA hypermethylation [14-18]. Most of these modulators have been studied in artificial cell line models for HIV-1 latency, but some of these mechanisms were found to be operational in resting $\mathrm{CD}_{4}^{+} \mathrm{T}$-cells from HIV infected patients $[19,20]$. HIV-1 transcriptional activation from latency depends on cellular transcription factors that bind to the Long Terminal Repeat (LTR) promoter. Differences in promoter activity among the HIV-1 subtypes have been reported, consistent with the fact that their LTRs have specific configurations of transcription factor-binding 
sites (TFBS), including variation in the number and sequence of NF $\kappa$ B, STAT5 and C/EBP sites [21-25]. Such subtype-specific promoter characteristics correlate with significant differences in terms of viral replication kinetics and the response to environmental changes [26]. The interaction between cell type specific transcription factors and LTR sites is crucial for the regulation of virus expression and possibly proviral latency. Therefore, we investigated the influence of the subtypespecific promoters on HIV-1 transcriptional latency in a single round infection-based latency assay model.

We demonstrate that the majority of the HIV-1 infected $\mathrm{T}$ cells initiate viral production only after TNFa activation. There were no gross differences in latency and activation properties among the subtypes, except for subtype AE. This subtype combines increased levels of productive infection with a reduced TNF $\alpha$ response, which correlates nicely with the presence of a GABP instead of an $\mathrm{NF} \kappa \mathrm{B}$ transcription factor binding site in its LTR.

\section{Results}

\section{Latency model}

We have previously described a single round infection assay to determine HIV-1 transcriptional latency, which occurs even in actively dividing $\mathrm{T}$ cells [27]. In this assay the SupT1 T cell line is infected with HIV-1 $1_{\text {LAI }}$ for 4 hours after which the fusion inhibitor T1249 is added to prevent new infections (Figure 1A). The culture is split 24 hours post infection and either treated with antilatency drugs or not (mock). Treated cells are harvested 24 hours later, fixed, stained for intracellular CA-p24 and analyzed by FACS. The living cell population was subsequently scored for intracellular CA-p24 production (Figure 1B).

First, we optimized the latency assay to score the impact of cellular stimuli on the HIV-1 subtype B strain LAI and tested the cytokine TNF $\alpha$ as anti-latency drug. The subtype B LTR promoter contains two NF $\kappa$ B binding sites through which transcription can be triggered by activation of the NF $\kappa \mathrm{B}$ pathway with TNF $\alpha$ [28-32]. In addition, $\mathrm{NF} \kappa \mathrm{B}$ stimulates transcriptional elongation by RNA Polymerase II through binding of the pTEFb cofactor [33]. We also tested Vorinostat (SAHA), an inhibitor of histone deacetylases, which creates a more open nucleosome conformation thereby making the HIV-1 promoter more accessible to transcription factors [34,35]. In the mock treated culture, $3.4 \%$ of the cells produced CA-p24, which increased to $10.1 \%$ in the TNF $\alpha$ treated culture (Figure 1C). The ratio between TNF $\alpha$ and mock treated cultures ("fold activation") is used as a measure of viral latency. TNF $\alpha$ treatment induced a significant 3fold increase in the percentage of CA-p24 positive cells (Figure 1D). In this assay, we only scored the productively infected cells, either directly or after drug treatment. We did not detect unresponsive or defective proviral genomes. The results indicated that there are at least 3 times as many latent integration events compared to productive integrations of an intact provirus in SupT1 $\mathrm{T}$ cells that can be activated upon TNF $\alpha$ treatment. Vorinostat has a less pronounced effect as CA-p24 positivity is increased from $3.4 \%$ to $4.8 \%$, yielding a 1.5 -fold activation. Combinations of both anti-latency drugs did not yield any further significant increases in activation over the TNF $\alpha$ effect (results not shown). In this setting of recently integrated proviruses, Vorinostat has no additional effect over the already strong effect of TNF $\alpha$. These results do not necessarily mean that all latently integrated proviruses are activated. It is likely that we cannot activate all latently integrated proviruses. Even latency studies using (clonal) cell lines, with each individual cell containing a latently integrated provirus, cannot purge $100 \%$ of the proviruses out of latency using a mixture of anti-latency drugs $[18,27,28,36-40]$.

TNF $\alpha$ stimulation affects the process of HIV-1 transcription, but might also affect the amount of proviruses generated upon cell stimulation. To exclude an effect of TNF $\alpha$ induction on the efficiency of reverse transcription and provirus formation, we performed a real-time TaqMan assay to score the average number of HIV-1 DNA copies per cell. We measured no difference between TNF $\alpha$ induced and mock treated after 24 hours of stimulation (data not shown), demonstrating that TNF $\alpha$ does not influence the efficiency of reverse transcription and/ or the amount of viral DNA that is produced, consistent with an exclusive impact on LTR-mediated transcription.

\section{Linear range of the latency model}

To investigate the linear range of this latency assay, we infected SupT1 cells with increasing amounts of subtype $\mathrm{B}$ and determined the percentage of CA-p24 positive cells with and without TNF $\alpha$ activation. Upon increasing the virus input, more cells become infected and TNF $\alpha$ activation yielded an increase in the percentage of CAp24 positive cells (Figure 2A). The fold activation, however, gradually decreased with increasing viral input (Figure 2B). A possible explanation for this is that at high viral input cells become infected by multiple viruses, with transcriptionally active proviruses 'overruling' silent copies. Such cells will be quantified as CA-p24 positive, leading to an underestimation of latent proviruses. At the other end of the spectrum, results became more variable and thus less reliable when less than 1\% CA-p24 positive cells were scored in the non-treated control. In subsequent infection experiments, we have titrated the virus such that 1 to $5 \%$ of the cells became CA-p24 positive without activation.

The results presented thus far demonstrate that TNF $\alpha$ treatment increases the number of CA-p24 producing 


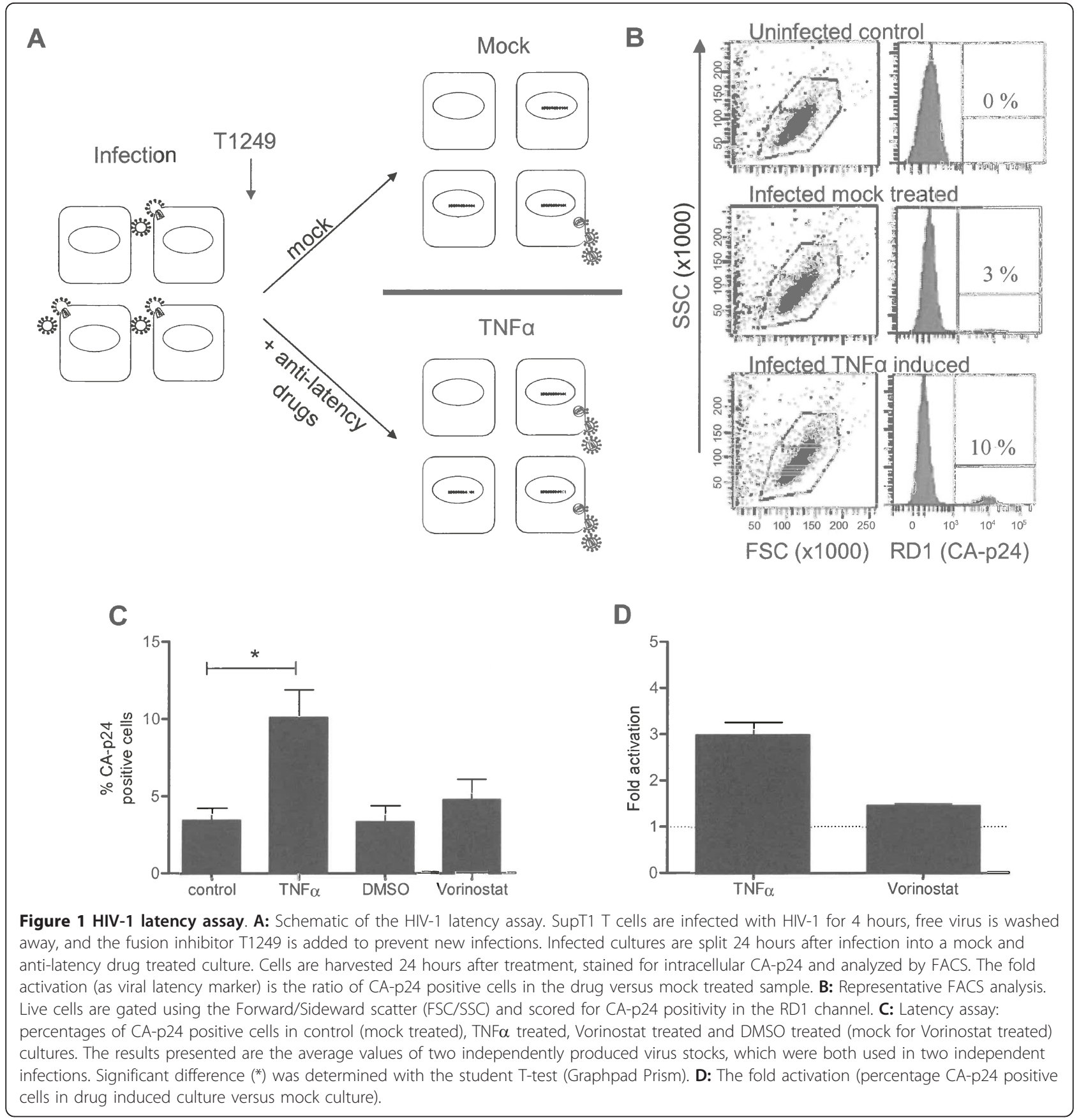

cells. To determine whether cells also start producing more CA-p24 upon TNF $\alpha$ stimulation, we analyzed the mean fluorescent intensity (MFI) of the CA-p24 positive cells. As with fold activation, we used MFI ratios of induced to non-treated cultures to determine the relative change in intracellular CA-p24 production level. This MFI ratio upon TNF $\alpha$ treatment was close to 1 , indicating that TNF $\alpha$ treatment does not increase the viral gene expression levels, but only the number of active proviruses (Figure 2C). To check whether perhaps more CA-p24 was secreted, the concentration of CAp24 in the culture supernatant was quantified by ELISA. The TNF $\alpha$ induced cultures showed increased CA-p24 levels in the supernatant since TNF $\alpha$ induced more cells to produce CA-p24 (Figure 2D). When we correlated the extracellular CA-p24 levels with the number of CAp24 producing cells, an increase was observed upon TNFa induction in the cultures infected with $3 \mathrm{ng}$ and 9 ng CA-p24 as viral input for infection. However, these differences were not statistically significant (Figure 2E). 

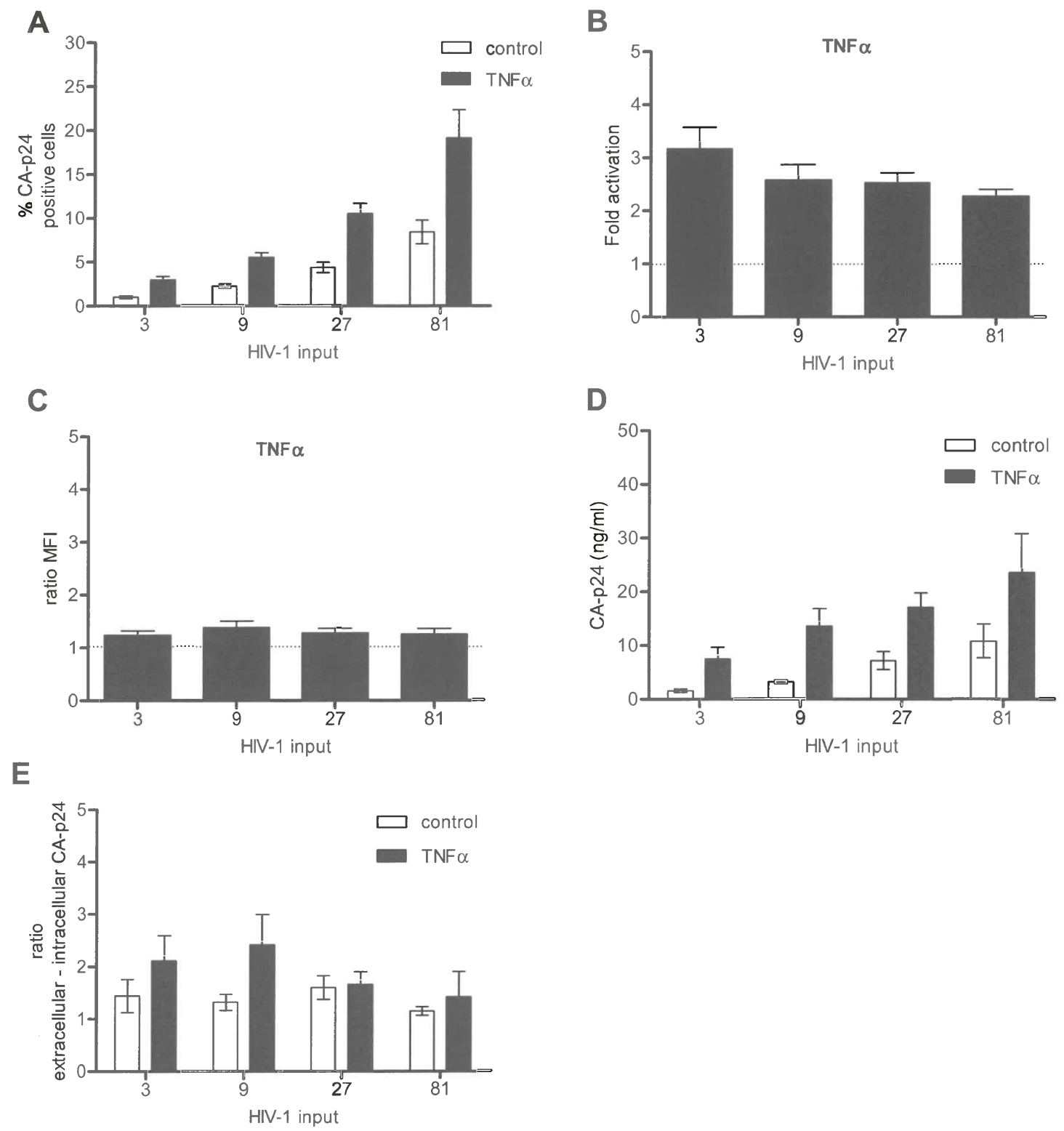

Figure 2 Performance of the HIV-1 latency assay. A: Average percentages of CA-p24 positive cells as determined by FACS in SupT1 T cells

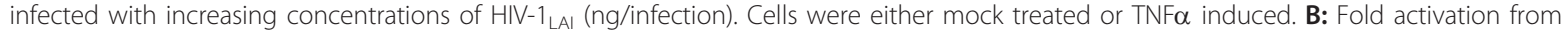
latency with increasing viral input. C: Ratio MFI of TNF $\alpha$ induced versus mock cultures. D: Extracellular CA-p24 concentrations in TNF $\alpha$ induced and mock treated cultures. E: The concentration of extracellular CA-p24 was corrected for the percentage of intracellular CA-p24 positive cells. Results are shown as the ratio of extracellular versus intracellular CA-p24. The results presented are the average values that were obtained with three independently produced virus stocks, and each stock was used for two independent infections.

Thus, the latency model optimized for the wild-type HIV-1 subtype B allows one to score for activation of latent proviruses.

\section{Latency over time}

We were interested in monitoring proviral latency over an extended time window. The fusion inhibitor T1249 remained present in these cultures to prevent spreading of the input virus. A sample of the cultures was split on day 2, 7 and 14 and either TNF $\alpha$ or mock treated. The cells were harvested 24 hours later and analyzed by FACS. The percentage of CA-p24 positive cells in the mock culture decreased gradually over time from $3.3 \%$ to $0.4 \%$ (Figure 3A). The TNF $\alpha$-treated level of CA-p24 positive cells also decreased, but less dramatically. This indicates that the fold activation as latency measurement 
A

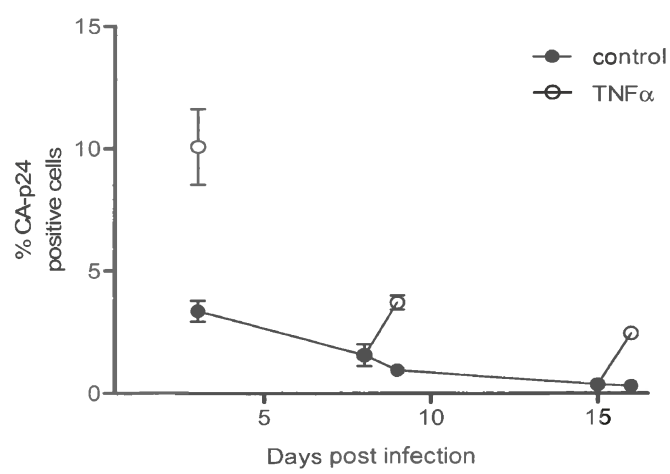

C

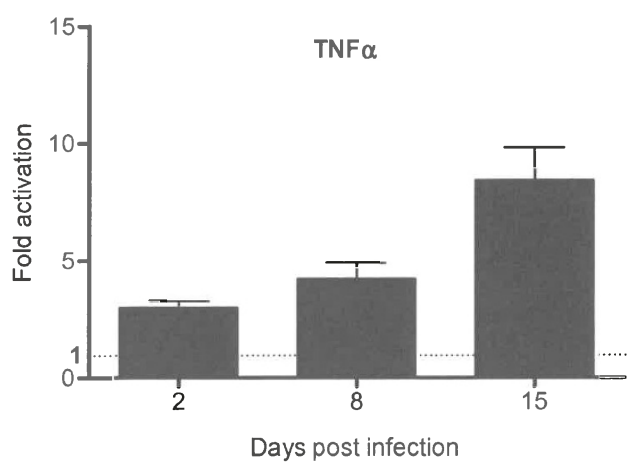

B

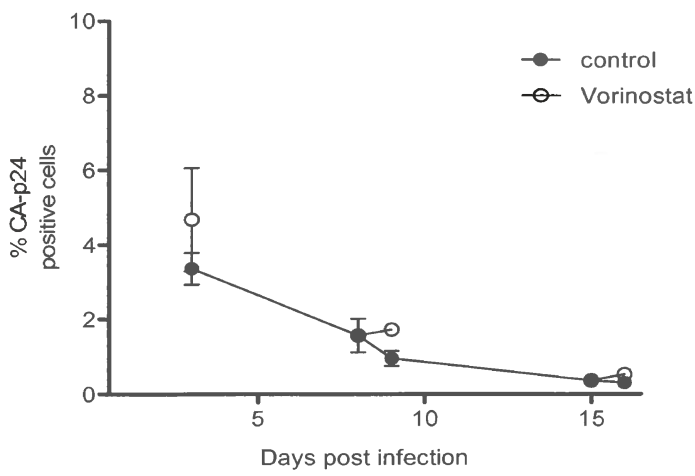

D

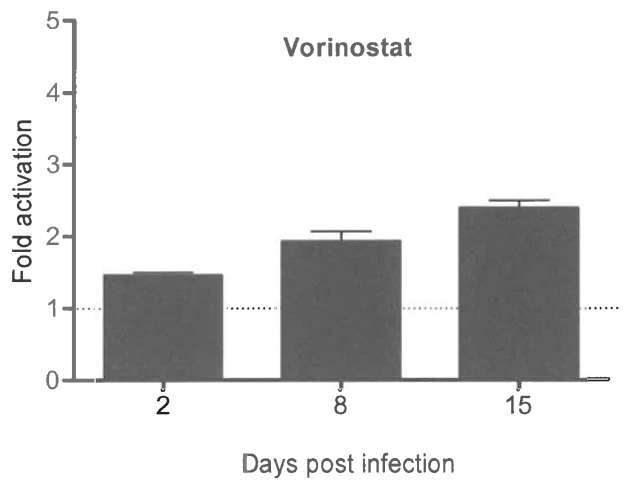

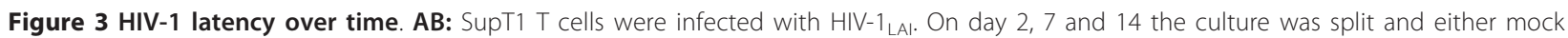
treated, induced with anti-latency drugs (TNF $\alpha$ or Vorinostat) or passaged and cultured for another week, when the protocol was repeated. Cells were harvested 24 hours after treatment (day 3, 8 and 15 respectively). Percentages of CA-p24 positive cells were determined by FACS. CD: The fold activation from latency. The results presented reflect the average of two independently produced virus stocks, and each was used in two independent infections.

increased considerably from 3 -fold on day 3 to 10 -fold on day 15 (Figure 3C). However, as described above, a too low percentage of CA-p24 positive cells yields less reproducible values, and we therefore decided to focus on the latency measurement after 24 hours. Nevertheless, the data in Figure $3 \mathrm{C}$ do clearly demonstrate that latency gets more dramatic over time.

Similar experiments were performed with the HDAC inhibitor Vorinostat (Figure 3B and 3D). Over time, both mock and Vorinostat treated cultures showed a decrease in number of CA-p24 positive cells, and the activation from latency increased from 1.5-fold on day 3 to 2.4-fold on day 15 .

\section{Latency properties of different HIV-1 subtypes and T cell lines}

To investigate the influence of the subtype-specific promoter on proviral latency, SupT1 cells were infected with an equal amount of the different viruses. Without inducers, subtype B yielded 3.4\% CA-p24 positive cells, which represented the basal transcription level (Figure 4A). The subtypes A, C, D, F and AG yielded very similar percentages, but subtypes $\mathrm{G}$ and $\mathrm{AE}$ demonstrated an increase in their basal transcription activity. Upon TNF $\alpha$ activation, percentages of CA-p24-producing cells increased for all subtypes, with an activation of around 3-fold, except for subtypes $\mathrm{G}$ and $\mathrm{AE}$ (Figure 4B). Activation of subtype $\mathrm{G}$ was only 2.2-fold, and subtype $\mathrm{AE}$ was even less potent at 1.5 -fold. Thus, subtypes with a higher basal transcription level were less inducible with TNF $\alpha$. In other words, subtypes $\mathrm{AE}$ and $\mathrm{G}$ proviruses were less prone to become latent. The HDAC inhibitor Vorinostat induced activation from latency for all subtypes, but with a reduced potency compared to TNF $\alpha$ (Figure 4C). However, the same subtype trends were apparent, with the highest activation for subtype $\mathrm{C}$ and the lowest induction for subtype AE.

We already showed that subtype B exhibits a more severe latency profile over time. The subtype-specific cultures were also assayed over longer periods, and the 


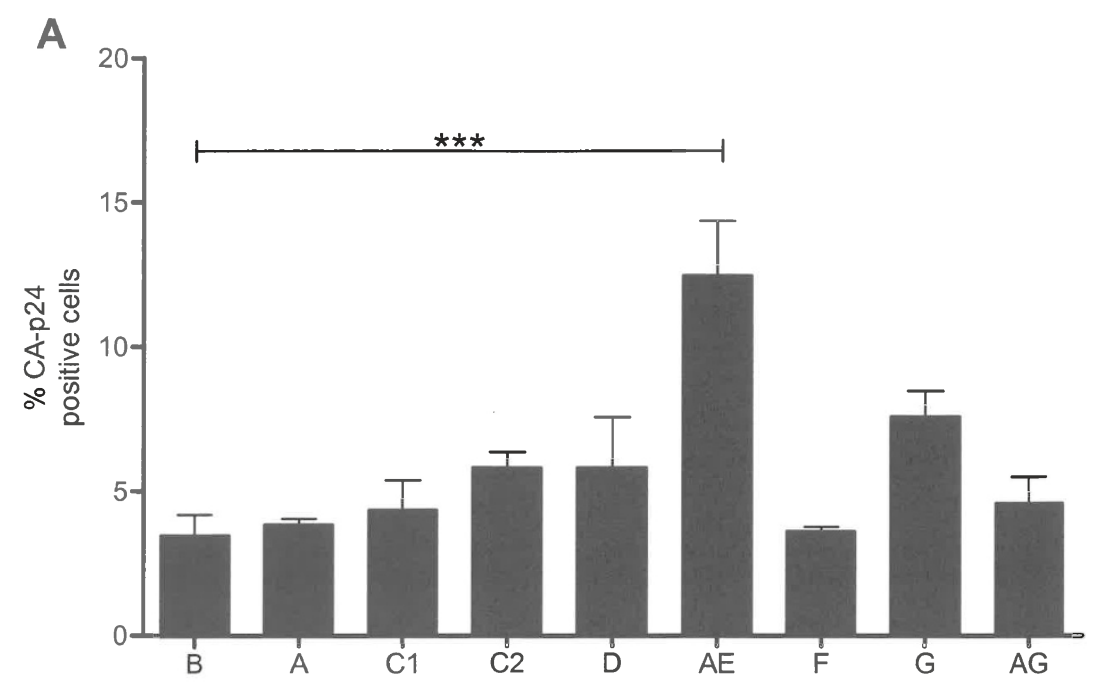

B

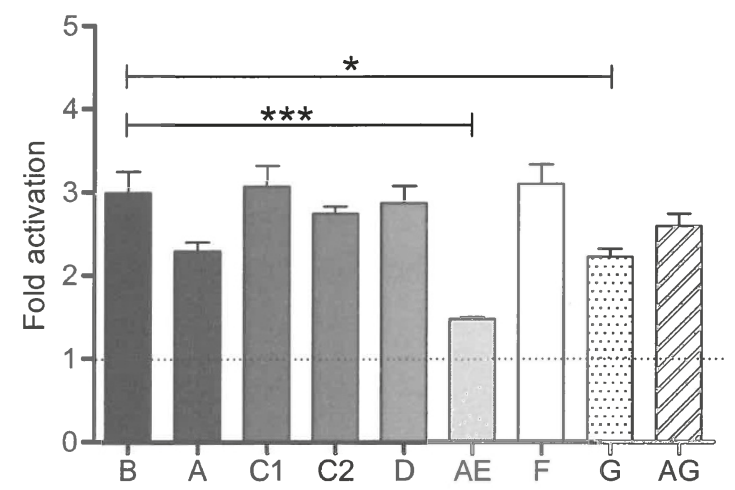

C

Vorinostat

Figure 4 Influence of the HIV-1 promoter on proviral latency. A: Viruses containing the indicated subtype specific LTR promoter were used in the latency assay. BC: Fold activation from latency with TNF $\alpha$ (B) and Vorinostat (C). The results are the average values that were obtained with two independently produced virus stocks, each tested in two independent infections. P values ${ }^{*}=p<0.05,{ }^{* *}=p<0.01,{ }^{* * *}=p<0.001$ were determined with the One Way ANOVA (Graphpad Prism).

latent provirus was activated with TNFa. Subtype G, which exhibits reduced latency compared to B, also obtains a more dramatic latency profile over time (Additional File 1 Fig. S1A). However, subtype AE activation from latency remains close to 1.5 -fold, the same latency value as measured at day 2 post infection. Thus, subtype $\mathrm{AE}$ infection starts with higher basal transcription levels, exhibits a reduced latency and the AE latency profile does not become more dramatic over time as observed for the other subtypes.

Similar experiments were performed with the HDAC inhibitor Vorinostat. As expected, activation does not reach similar levels as TNF $\alpha$ treatment (Additional file 1, Fig. S1B). Again, subtype AE was less prone to activation by Vorinostat as compared to the other subtypes.
Compared to subtype $\mathrm{B}, \mathrm{AE}$ has increased basal transcription levels and shows reduced latency. To ensure that the measurements were still in the linear range of the assay, SupT1 cells were infected with different amounts of subtype AE or B virus. As expected, the basal percentage of CA-p24 positive cells was always higher for AE than B (Figure 5A). Likewise, the fold activation was always higher for B than AE. Additionally, the TNF $\alpha$ induced activation from latency for subtype $\mathrm{AE}$ remained around 1.5-fold (Figure 5B). These results demonstrate that subtype $\mathrm{AE}$ measurements are within the linear range of the assay and, more importantly, that $\mathrm{AE}$ is less responsive to $\mathrm{TNF} \alpha$ induction since the $\mathrm{AE}$ promoter activity is higher compared to $\mathrm{B}$ at basal settings. 

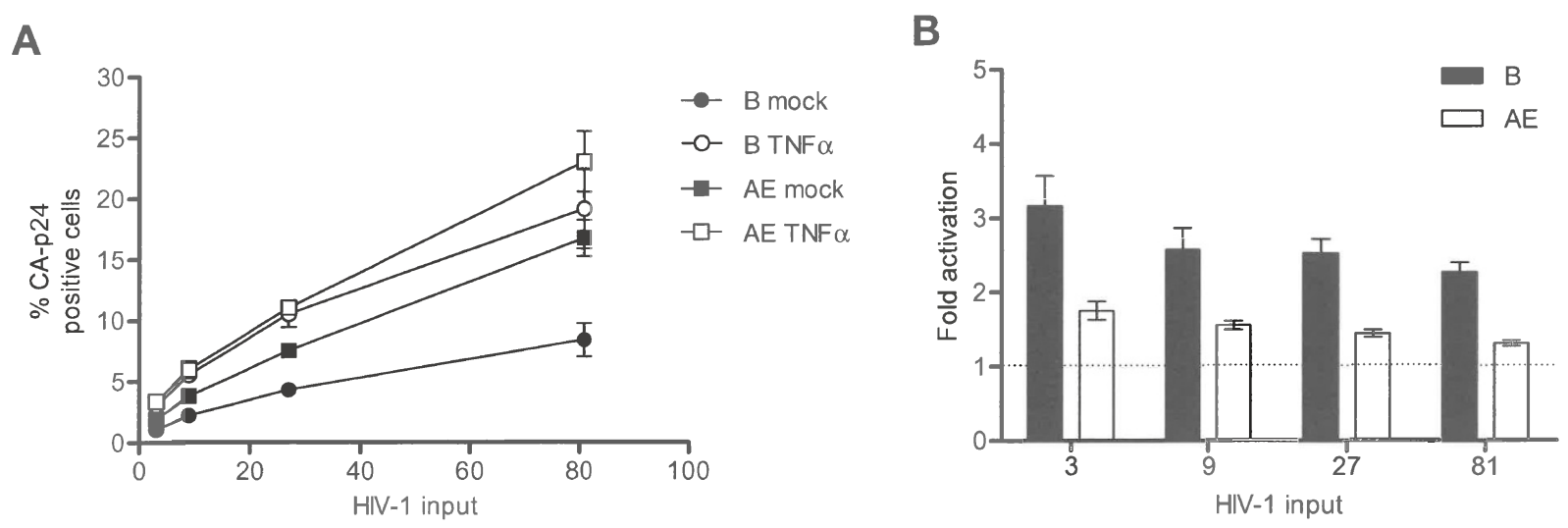

Figure $\mathbf{5}$ Latency profile comparison of HIV-1 subtypes AE and B. A: SupT1 T cells were infected with increasing virus concentrations of subtype $B$ or $\operatorname{AE}(3,9,27$ and 81 ng/infection CA-p24) in the presence or absence of TNF $\alpha$. B: Fold activation with TNF $\alpha$ for subtypes AE and B with the indicated viral inputs. The results presented reflect the average of three independently produced virus stocks and each stock was used in two independent infections. The HIV-1 input (ng/infection) was based on CA-p24 ELISA.

To investigate if the obtained results are specific for SupT1 cells, we repeated the experiments in Jurkat cells because many HIV-1 latency studies have been performed using this $\mathrm{T}$ cell line $[17,18,30,38]$. The percentage of CA-p24 positive cells without induction, reflecting the basal transcription level, was slightly higher for $\mathrm{AE}$ as compared to $\mathrm{B}$ (1.2 and 1.0\% respectively, Additional File 2, Fig. S2A). However, activation from latency by $\mathrm{TNF} \alpha$ induction was significantly higher for B than for AE (Additional File 2, Fig. S2B). These results demonstrate that subtype $\mathrm{AE}$ also exhibits reduced latency compared to subtype $B$ in the Jurkat $\mathrm{T}$ cell line.

\section{$\mathrm{NF} \kappa \mathrm{B}$ versus $\mathrm{GABP}$}

Infection of $\mathrm{T}$ cells with HIV-1 subtype AE yields more CA-p24 producing cells than equivalent infections with subtype B. On the other hand, TNF $\alpha$ induced activation from latency is reduced for AE compared to B, which thus yield similar end production levels. Arguably, the AE LTR might be less prone to become silenced due to the presence of the unique GABP binding site instead of the regular second $\mathrm{NF} \kappa \mathrm{B}$ site present in the other subtypes. The GA binding protein (GABP) complex is composed of two subunits. GABP $\alpha$ binds to the DNA and GABP $\beta$ contains the transcriptional transactivation domain. This transcription factor has been demonstrated to have a role in basic cellular functions and has recently been described to have a critical role in differentiation and maintenance of hematopoietic progenitor cells [41]. To investigate if the GABP binding site is responsible for the increased basal transcription level and decreased TNF $\alpha$ response, we made several alterations in the two promoters and tested latency properties (Figure 6A). Replacing the GABP with a second NF $\kappa$ B binding site in the $\mathrm{AE}$ promoter $(\mathrm{AE}+2 \mathrm{xNF} \kappa \mathrm{B})$ slightly decreased the basal transcription level and subsequently increased the TNF $\alpha$ response (Figure 6BC). Activation from latency increases significantly from 1.6-fold for AE to 2.3-fold for $\mathrm{AE}+2 \mathrm{xNF} \kappa \mathrm{B}$. To examine if GABP is the sole factor that is responsible for this effect, we subsequently converted the upstream NF $\kappa$ B into a GABP site in subtype B $(\mathrm{B}+\mathrm{GABP})$. The basal transcription level increased from 2.3 for $B$ to 3.1 for B+GABP, which is not statistically significant. However, the GABP insertion altered the TNF $\alpha$ response which decreased significantly from 2.6-fold for $B$ to 1.9-fold for B+GABP. Taken together, these results demonstrate that the NFkB to GABP conversion partially explains the higher basal activity combined with lower response to activation but that GABP is probably not the sole responsible factor.

\section{Discussion}

HIV-1 proviral latency is a major barrier towards virus eradication from the infected patient. This latent virus reservoir is established early in infection $[7,12]$. In this manuscript, we introduce a latency model system that creates the opportunity to study proviral latency in actively dividing $\mathrm{T}$ cells. The model is based upon a single round infection in combination with FACS analysis to determine virus production per cell. A major advantage of this model system is the use of wild type HIV-1 instead of plasmids or sub-genomic reporter constructs. Additionally, the infected cells do not need to be cultured for an extended period, thus allowing one to study latency directly after infection in wild type cells without selection, in contrast to previous described latency model cell lines such as U1, ACH-2, OM-10.1 and J-Lat [42-45]. In principle, our method can be applied to any type of cell susceptible to HIV-1 infection. 


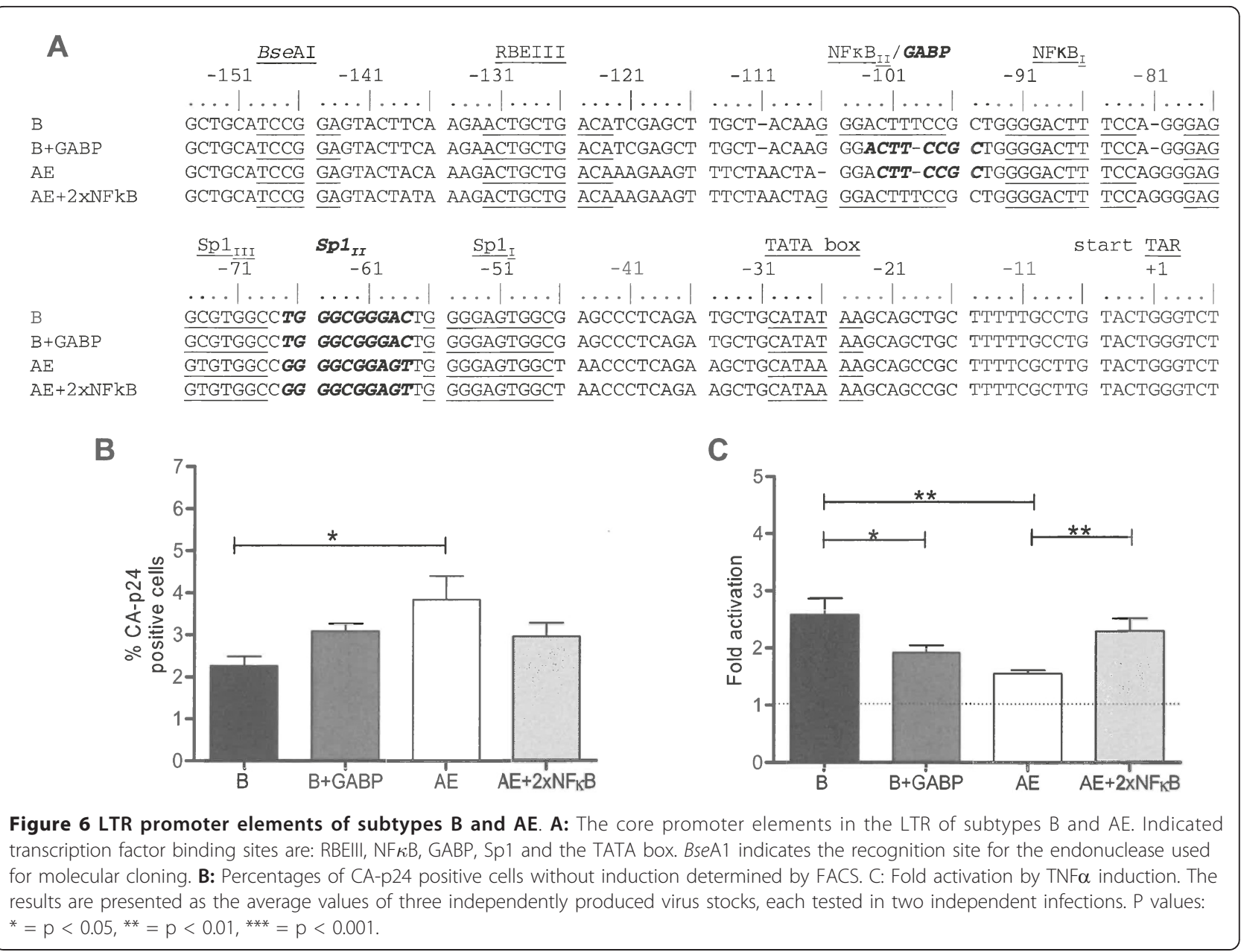

In an acute HIV-1 infection model with the SupT1 $\mathrm{T}$ cell line, we demonstrate that a low percentage of the infected cells is able to express the integrated provirus. The majority of infected cells carry a latent provirus, which we could identify upon provirus activation from latency by TNF $\alpha$. For HIV-1 subtype B, we measured a 3 -fold increase in the percentage of CA-p24 positive cells. However, the amount of viral CA-p24 production per producing cell did not increase. The HDAC inhibitor Vorinostat was also able to activate latent provirus, although less efficient than TNF $\alpha$. Combinations of both anti latency drugs did not yield any further significant increases in activation.

Culturing the infected cells over an extended period caused a relative decrease in the number of CA-p24 positive cells. Transcriptional silencing of active proviruses seems unlikely because we use actively dividing $\mathrm{T}$ cells. It seems more likely that the decrease in percentage of CAp24 positive cells is due to cell death induced by HIV-1 [46]. In addition, as HIV-1 induces cell cycle arrest [47], virus producing cells can no longer proliferate, and thus their percentage will gradually decline relative to uninfected cells. Considering both factors, the decrease in CA-p24 positive cells seems relatively slow. This might be due to replenishment of the CA-p24 producing population by cells with a latent provirus that becomes transcriptionally active, which is in agreement with the stochastic model of HIV-1 reactivation [48-50]. We demonstrate that latent proviruses remain present, as TNF $\alpha$ was still able to induce a significant increase in the CA-p24 positive population at day 15 . In fact, activation increased from 3 -fold at day 2 to 10 -fold at day 15 . However, the absolute percentage of CA-p24 positive cells obtained upon TNF $\alpha$ treatment decreases over time. The latter observation further supports the hypothesis of stochastic activation of latently integrated provirus, causing this population to slowly decline. Alternatively, some of the latent proviruses may become silenced more stringently over time such that TNF $\alpha$ no longer suffices for activation. We are currently studying both options.

We have analyzed the promoter of different HIV-1 subtypes and observed that subtypes A, C, D, F and AG have similar latency profiles as $\mathrm{B}$. Interestingly, the promoter of subtype $C$ contains a third consensus DNA sequence 
for $\mathrm{NF} \kappa \mathrm{B}$ binding [51]. Although it has not been shown that this site is actually bound by $\mathrm{NF} \kappa \mathrm{B}$, experiments with LTR-luciferase reporter plasmids have demonstrated that subtype $\mathrm{C}$ promoter activity is increased compared to subtype B upon stimulation with TNF $\alpha$ or other $\mathrm{NF} \kappa \mathrm{B}$ activators [22,25,38,52-54]. Viral fitness studies have also demonstrated relative advantages for the subtype C promoter in a TNF $\alpha$-rich environment [26]. However, in terms of proviral latency, we did not observe a significant difference between $\mathrm{C}$ and the other subtypes.

Subtype AE clearly exhibits a reduced level of latency, which correlates with a GABP instead of NF $\kappa \mathrm{B}$ transcription factor binding site in the LTR. The GABP-to$\mathrm{NF} \kappa \mathrm{B}$ mutation in the $\mathrm{AE}$ promoter only slightly reduced the basal transcription level but did restore the TNF $\alpha$ response. The reciprocal experiment, the NF $\kappa \mathrm{B}-$ to-GABP switch in subtype B, did not alter the basal levels but did significantly reduce the TNF $\alpha$ response. Thus, the GABP site is an important (but probably not the sole) determinant of the subtype AE specific properties. We are currently investigating other sequence variations between subtype $\mathrm{AE}$ and $\mathrm{B}$ to further elucidate the observed differences.

Opijnen et al. demonstrated that the LTR impact on viral replication depends on the cellular environment, either by host cell type or the presence of activators [26]. Subtype AE out-competed all other subtypes in the SupT1 T cell line. However, subtype AE became the worst competitor upon TNF $\alpha$ addition. Our observations indicate that the $\mathrm{AE}$ promoter has an advantage over the other subtype-specific promoters in a TNF $\alpha$-poor environment, in part due to the unique GABP site causing AE to become latent less frequently than the other subtypes. Interestingly, a long-term culture of SupT1 T cells infected with a Tat-defective poorly replicating, $\mathrm{HIV}-1_{\mathrm{LAI}}$ variant, resulted in a spontaneous NF $\kappa \mathrm{B}$-to-GABP conversion, which significantly increased viral replication [55]. This also indicates strong differences between subtypes AE and B in their replication and latency profiles. Because subtype AE proviruses are less prone to become latent, this may translate in higher chances of purging the reservoir. In other words, a cure may be within closer reach for subtype AE infected individuals.

\section{Conclusions}

We used a novel model of HIV-1 infection to study proviral latency in actively dividing $\mathrm{T}$ cells, of which the majority only support viral gene expression after TNF $\alpha$ activation. We measured no gross differences among the HIV-1 subtypes, both in the initial latency property and the activation response, except for subtype AE that combines an increased level of basal transcription with a reduced TNF $\alpha$ response. This subtype AE property is related to the presence of a GABP instead of $\mathrm{NF} \kappa \mathrm{B}$ binding site in the viral LTR promoter.

\section{Methods \\ Cells and viruses}

HEK 293T cells were grown as a monolayer in Dulbecco's minimal essential medium supplemented with $10 \%(\mathrm{v} / \mathrm{v})$ fetal calf serum (FCS), $40 \mathrm{U} / \mathrm{ml}$ penicillin, $40 \mu \mathrm{g} / \mathrm{ml}$ streptomycin, $20 \mathrm{mM}$ glucose and minimal essential medium nonessential amino acids at $37^{\circ} \mathrm{C}$ and $5 \% \mathrm{CO}_{2}$. The human T lymphocytic cell lines SupT1 (ATCC CRL-1942) [56] and Jurkat (ATCC TIB-152) were cultured in advanced RPMI 1640 medium (Gibco BRL, Gaithersburg, MD) supplemented with $1 \%(\mathrm{v} / \mathrm{v}) \mathrm{FCS}, 40 \mathrm{U} / \mathrm{ml}$ penicillin, and $40 \mu \mathrm{g} / \mathrm{ml}$ streptomycin at $37^{\circ} \mathrm{C}$ and $5 \% \mathrm{CO}_{2}$. HIV-1 infections were performed with $293 \mathrm{~T}$ produced virus stocks of the different HIV-1 molecular clones. The cells were transfected with plasmid DNA of the HIV-1 LAI molecular clone [57] or derivates thereof by the calcium phosphate method as described previously [58]. LTRs from patient isolates representing subtype $A, C, D, A E$ (CRF_01), F, G and AG (CRF_02) were selected as being representative of the viral quasi species in the patient and the HIV-1 subtypes [22]. These subtype-specific LTRs were cloned into the common viral backbone of HIV-1 $1_{\text {LAI }}$ (subtype B). The recombinant viruses are isogenic except for the core promoter region containing the major TFBS, thus preventing differences in fusion, integration etc. The variable LTR region spans only $150 \mathrm{bp}$, containing the major TFBS, but still encoding a subtype B TAR hairpin. The concentration of the produced virus stocks was determined by CA-p24 ELISA.

\section{Reagents}

TNFa (Invitrogen PHC3015) was prepared in sterile milliQ $\mathrm{H}_{2} \mathrm{O}$ (stock solution $10 \mu \mathrm{g} / \mathrm{ml}$ ) and used at a final concentration of $50 \mathrm{ng} / \mathrm{ml}$. Fusion inhibitor T1249 (WQEWEQKITALLEQAQIQQEKNEYELQKL DKWASLWEWF, Pepscan Therapeutics BV, Lelystad, the Netherlands) was obtained as a $10.000 \times$ stock solution of $1 \mathrm{mg} / \mathrm{ml}$. Vorinostat was donated by Frank Dekker (Groningen University, the Netherlands). The lyophilized powder was dissolved in DMSO (2 mM stock solution) and used at a final concentration of $0.3 \mu \mathrm{M}$.

\section{HIV-1 latency assay Single round infection assay}

SupT1 or Jurkat T cells $\left(0.5 \times 10^{6}\right.$ cells $)$ were infected with virus stocks of the primary CXCR4-using LAI isolate or derivatives containing a subtype-specific 3'LTR. Excess virus was washed away after four hours and the cells were cultured in the presence of the fusion inhibitor 
T1249 to block all subsequent viral entry. The cultures were split 24 hours post-infection, and TNF $\alpha$ was added to a single culture. After another 24 hours, we measured intracellular CA-p24 by FACS analysis and extracellular CA-p24 production in the culture medium by ELISA. To equalize infections, input CA-p24 was kept similar among subtype-specific infections and conditional medium was added to reach a $200 \mu \mathrm{l}$ infection volume.

\section{Intracellular CA-p24 staining and fluorescence-activated cell} sorting

Flow cytometry was performed with RD1- or FITC-conjugated mouse monoclonal anti-CA-p24 (clone KC57, Coulter). Cells were fixed in $4 \%$ formaldehyde for at least $5 \mathrm{~min}$ at room temperature, washed with FACS buffer (PBS with 10\% FCS) and kept at $4^{\circ} \mathrm{C}$. The cells were washed with BD Perm/Wash ${ }^{\mathrm{TM}}$ buffer (BD Pharmingen) and stained for at least 30 minutes at $4^{\circ} \mathrm{C}$ with the appropriate antibody diluted 1:100 in BD Perm/ Wash ${ }^{\mathrm{TM}}$ buffer. Excess antibody was removed by washing the cells with BD Perm/Wash ${ }^{\mathrm{TM}}$ buffer and the cells were resuspended in FACS buffer. Cells were analyzed on a BD FACSCanto II flow cytometer with BD FACSDiva Software v6.1.2 (BD biosciences, San Jose, CA). Cell populations were defined based on forward/sideward scattering. Results from different assays were corrected for between-session variation with the factor correction program [59].

\section{Extracellular CA-p24 ELISA}

Culture supernatant was heat inactivated at $56^{\circ} \mathrm{C}$ for 30 minutes in the presence of $0.05 \%$ Empigen-BB (Calbiochem, La Jolla, USA). The CA-p24 concentration was determined by a twin-site ELISA with D7320 (Biochrom, Berlin, Germany) as capture antibody and alkaline phosphatase-conjugated anti-p24 monoclonal antibody (EH12AP) as detection antibody. Quantification was performed with the lumiphos plus system (Lumigen, Michigan, USA) in a LUMIstar Galaxy (BMG labtechnologies, Offenburg, Germany) luminescence reader. Recombinant CA-p24 produced in a baculovirus system was used as a standard.

\section{Plasmids}

Cloning of the different subtype specific LTRs (A, C1. C2, $\mathrm{D}, \mathrm{AE}=\mathrm{CRF} 01, \mathrm{~F}, \mathrm{G}$ and $\mathrm{AG}=\mathrm{CRF} 02)$ into the full length LAI molecular clone has been described previously [22]. Subtype $\mathrm{C} 1$ and $\mathrm{C} 2$ do not refer to the different $\mathrm{C}$ subclusters, $C$ and $C$, but resemble two variants within subcluster $C[60,61]$. Introduction of the GABP instead of the upstream $\mathrm{NF} \kappa \mathrm{B}$ site in the promoter of subtype B has previously been described [55]. An additional construct was made converting the unique GABP site in the subtype AE LTR into a second NF $\kappa$ B site. Plasmid pBlue3'LTR AE [22] was used as template in two independent PCR reactions under standard conditions. PCR primers 5' TAG
GGA CTT TCC GCT GGG GAC TTT CC3' and 5'TGT CTC ATG AGC GGA TAC ATA3' were used in reaction A (italics indicate the NF $\kappa \mathrm{B}$-II site). Reaction B was performed with primers 5'GTC CCC TGC GGA AAG TCC CTA GTT AG3' and 5'TGG AAG GGC TAA TTC ACT CCC3'. Both PCR products, purified from gel, were used as templates in a third PCR under standard conditions with primers 5'TGT CTC ATG AGC GGA TAC ATA3' and 5'TGG AAG GGC TAA TTC ACT CCC3'. The 833 bp PCR product was digested with BseA1 and HindIII, purified and ligated into pBlue3'LTR. The mutated subtype AE LTR was cloned from pBlue3'LTR into pLAI [57] using the $\mathrm{XhoI}$ and $B g l \mathrm{I}$ restriction sites and verified by sequencing.

\section{Quantitative TaqMan assay}

TaqMan assays were used to quantify the number of HIV-1 DNA copies in infected cultures. In brief, cells were resuspended in Tris-EDTA $(10 \mathrm{mM} \mathrm{pH}$ 8.3) containing 0.5 units $/ \mu$ l proteinase $\mathrm{K}$ (Roche Applied Science), incubated for 1 hour at $56^{\circ} \mathrm{C}$ and $10 \mathrm{~min}$ at $95^{\circ} \mathrm{C}$ and directly used for PCR amplification. The number of input cells was determined using TaqMan ${ }^{\circledR}$ reagents for quantification of $\beta$-actin DNA (AB, Applied Biosystems) according to the manufacturer's instruction. HIV-1 DNA was detected with a semi-nested real-time PCR assay with a pre-amplification step that is exclusive for completely reverse transcribed HIV-1 DNA. The pre-amplified product was subsequently quantified by real-time PCR as previously described [62].

\section{Additional material}

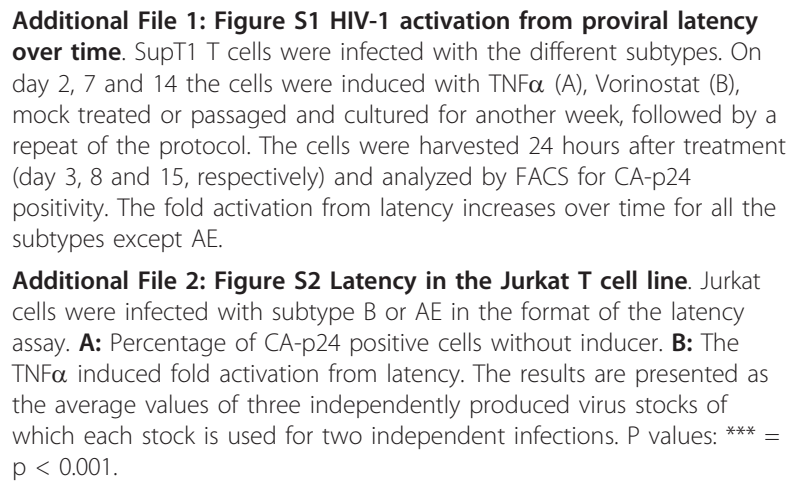

Additional File 2: Figure S2 Latency in the Jurkat T cell line. Jurkat cells were infected with subtype B or AE in the format of the latency assay. A: Percentage of CA-p24 positive cells without inducer. B: The TNF $\alpha$ induced fold activation from latency. The results are presented as the average values of three independently produced virus stocks of which each stock is used for two independent infections. $P$ values: ${ }^{* *}=$ $\mathrm{p}<0.001$.

\section{Acknowledgements}

We thank S. Heijnen for performing CA-p24 ELISA, F. Dekker and H. Haisma (Rijksuniversiteit Groningen, The Netherlands) for the kind gift of Vorinostat, J.A. Dobber for maintenance of the BD FACSCanto II, D. Speijer, E.M. Westerhout and J.J.M Eekels for very helpful discussions and reading the manuscript. Research was supported by the Dutch AIDS Fund (AIDS Fonds 2007028 and 2008014). 


\section{Authors' contributions}

RMvdS was responsible for the majority of the experimental work, data analysis and drafted the manuscript. GP and MLVG have contributed to the experimental work. BB has contributed to the study design and writing the manuscript. REJ was responsible for the study design and writing the manuscript. All authors read and approved the final manuscript.

\section{Competing interests}

The authors declare that they have no competing interests.

Received: 2 May 2011 Accepted: 16 September 2011 Published: 16 September 2011

\section{References}

1. Chun TW, Davey RT Jr, Engel D, Lane HC, Fauci AS: Re-emergence of HIV after stopping therapy. Nature 1999, 401:874-875.

2. Wong JK, Hezareh M, Gunthard HF, Havlir DV, Ignacio CC, Spina CA Richman DD: Recovery of replication-competent HIV despite prolonged suppression of plasma viremia. Science 1997, 278:1291-1295.

3. Chun TW, Stuyver L, Mizell SB, Ehler LA, Mican JA, Baseler M, Lloyd AL, Nowak MA, Fauci AS: Presence of an inducible HIV-1 latent reservoir during highly active antiretroviral therapy. Proc Natl Acad Sci USA 1997, 94:13193-13197.

4. Schmid A, Gianella S, von Wyl V, Metzner KJ, Scherrer AU, Niederost B, Althaus CF, Rieder P, Grube C, Joos B, Weber R, Fischer M, Gunthard HF: Profound depletion of HIV-1 transcription in patients initiating antiretroviral therapy during acute infection. PLoS One 2010, 5:e13310.

5. Finzi D, Blankson J, Siliciano JD, Margolick JB, Chadwick K, Pierson T, Smith K, Lisziewicz J, Lori F, Flexner C, Quinn TC, Chaisson RE, Rosenberg E, Walker B, Gange S, Gallant J, Siliciano RF: Latent infection of CD4+ T cells provides a mechanism for lifelong persistence of HIV-1, even in patients on effective combination therapy. Nat Med 1999, 5:512-517.

6. Siliciano JD, Kajdas J, Finzi D, Quinn TC, Chadwick K, Margolick JB, Kovacs C, Gange SJ, Siliciano RF: Long-term follow-up studies confirm the stability of the latent reservoir for HIV-1 in resting CD4+ T cells. Nat Med 2003, 9:727-728.

7. Chun TW, Engel D, Berrey MM, Shea T, Corey L, Fauci AS: Early establishment of a pool of latently infected, resting CD4(+) T cells during primary HIV-1 infection. Proc Natl Acad Sci USA 1998, 95:8869-8873.

8. Bailey JR, Sedaghat AR, Kieffer T, Brennan T, Lee PK, Wind-Rotolo M, Haggerty CM, Kamireddi AR, Liu Y, Lee J, Persaud D, Gallant JE, Cofrancesco J Jr, Quinn TC, Wilke CO, Ray SC, Siliciano JD, Nettles RE, Siliciano RF: Residual human immunodeficiency virus type 1 viremia in some patients on antiretroviral therapy is dominated by a small number of invariant clones rarely found in circulating CD4+ T cells. J Virol 2006, 80:6441-6457.

9. Chun TW, Carruth L, Finzi D, Shen X, DiGiuseppe JA, Taylor H, Hermankova M, Chadwick K, Margolick J, Quinn TC, Kuo YH, Brookmeyer R, Zeiger MA, Barditch-Crovo P, Siliciano RF: Quantification of latent tissue reservoirs and total body viral load in HIV-1 infection. Nature 1997, 387:183-188.

10. Chun TW, Davey RT Jr, Ostrowski M, Shawn JJ, Engel D, Mullins JI, Fauci AS: Relationship between pre-existing viral reservoirs and the re-emergence of plasma viremia after discontinuation of highly active anti-retroviral therapy. Nat Med 2000, 6:757-761.

11. Zhu T, Muthui D, Holte S, Nickle D, Feng F, Brodie S, Hwangbo Y, Mullins Jl, Corey L: Evidence for human immunodeficiency virus type 1 replication in vivo in CD14(+) monocytes and its potential role as a source of virus in patients on highly active antiretroviral therapy. J Virol 2002, 76:707-716.

12. Dinoso JB, Rabi SA, Blankson JN, Gama L, Mankowski JL, Siliciano RF, Zink MC, Clements JE: A simian immunodeficiency virus-infected macaque model to study viral reservoirs that persist during highly active antiretroviral therapy. J Virol 2009, 83:9247-9257.

13. Imamichi H, Degray G, Asmuth DM, Fischl MA, Landay AL, Lederman MM, Sereti I: HIV-1 viruses detected during episodic blips following interleukin-7 administration are similar to the viruses present before and after interleukin-7 therapy. AIDS 2010.

14. El Kharroubi A, Piras G, Zensen R, Martin MA: Transcriptional activation of the integrated chromatin-associated human immunodeficiency virus type 1 promoter. Mol Cell Biol 1998, 18:2535-2544.
15. Ishida T, Hamano A, Koiwa T, Watanabe T: $5^{\prime}$ long terminal repeat (LTR)selective methylation of latently infected HIV-1 provirus that is demethylated by reactivation signals. Retrovirology 2006, 3:69.

16. Huang J, Wang F, Argyris E, Chen K, Liang Z, Tian H, Huang W, Squires K, Verlinghieri G, Zhang H: Cellular microRNAs contribute to HIV-1 latency in resting primary CD4+ T lymphocytes. Nat Med 2007, 13:1241-1247.

17. Blazkova J, Trejbalova K, Gondois-Rey F, Halfon P, Philibert P, Guiguen A, Verdin E, Olive D, van Lint C, Hejnar J, Hirsch I: CpG methylation controls reactivation of HIV from latency. PLoS Pathog 2009, 5:e1000554.

18. Kauder SE, Bosque A, Lindqvist A, Planelles V, Verdin E: Epigenetic regulation of HIV-1 latency by cytosine methylation. PLoS Pathog 2009, 5: e1000495.

19. Archin NM, Keedy KS, Espeseth A, Dang H, Hazuda DJ, Margolis DM: Expression of latent human immunodeficiency type 1 is induced by novel and selective histone deacetylase inhibitors. AIDS 2009, 23:1799-1806.

20. Yukl S, Pillai S, Li P, Chang K, Pasutti W, Ahlgren C, Havlir D, Strain M, Gunthard H, Richman D, Rice AP, Daar E, Little S, Wong JK: Latentlyinfected CD4+ T cells are enriched for HIV-1 Tat variants with impaired transactivation activity. Virology 2009, 387:98-108.

21. Crotti A, Chiara GD, Ghezzi S, Lupo R, Jeeninga RE, Liboi E, Lievens PM, Vicenzi E, Bovolenta C, Berkhout B, Poli G: Heterogeneity of signal transducer and activator of transcription binding sites in the longterminal repeats of distinct HIV-1 subtypes. Open Virol J 2007, 1:26-32.

22. Jeeninga RE, Hoogenkamp M, Armand-Ugon M, de Baar M, Verhoef K, Berkhout B: Functional differences between the long terminal repeat transcriptional promoters of human immunodeficiency virus type 1 subtypes A through G. J Virol 2000, 74:3740-3751.

23. Nabel $G$, Baltimore $D$ : An inducible transcription factor activates expression of human immunodeficiency virus in T cells. Nature 1987, 326:711-713.

24. Liu Y, Nonnemacher MR, Stauff DL, Li L, Banerjee A, Irish B, Kilareski E, Rajagopalan N, Suchitra JB, Khan ZK, Ranga U, Wigdahl B: Structural and functional studies of CCAAT/enhancer binding sites within the human immunodeficiency virus type 1 subtype C LTR. Biomed Pharmacother 2010.

25. Montano MA, Novitsky VA, Blackard JT, Cho NL, Katzenstein DA, Essex M: Divergent transcriptional regulation among expanding human immunodeficiency virus type 1 subtypes. J Virol 1997, 71:8657-8665.

26. van Opijnen $T$, Jeeninga RE, Boerlijst MC, Pollakis GP, Zetterberg $V_{\text {, }}$ Salminen M, Berkhout B: Human immunodeficiency virus type 1 subtypes have a distinct long terminal repeat that determines the replication rate in a host-cell-specific manner. J Virol 2004, 78:3675-3683.

27. Jeeninga RE, Westerhout EM, van Gerven ML, Berkhout B: HIV-1 latency in actively dividing human T cell lines. Retrovirology 2008, 5:37.

28. Williams SA, Kwon H, Chen LF, Greene WC: Sustained induction of NFkappa $B$ is required for efficient expression of latent human immunodeficiency virus type 1. J Virol 2007, 81:6043-6056.

29. West MJ, Lowe AD, Karn J: Activation of human immunodeficiency virus transcription in T cells revisited: NF-kappaB p65 stimulates transcriptional elongation. J Virol 2001, 75:8524-8537.

30. Duverger A, Jones J, May J, Bibollet-Ruche F, Wagner FA, Cron RQ, Kutsch O: Determinants of the establishment of human immunodeficiency virus type 1 latency. J Virol 2009, 83:3078-3093.

31. Folks TM, Clouse KA, Justement J, Rabson A, Duh E, Kehrl JH, Fauci AS: Tumor necrosis factor alpha induces expression of human immunodeficiency virus in a chronically infected T-cell clone. Proc Natl Acad Sci USA 1989, 86:2365-2368.

32. Duh EJ, Maury WJ, Folks TM, Fauci AS, Rabson AB: Tumor necrosis factor alpha activates human immunodeficiency virus type 1 through induction of nuclear factor binding to the NF-kappa B sites in the long terminal repeat. Proc Natl Acad Sci USA 1989, 86:5974-5978.

33. Barboric M, Nissen RM, Kanazawa S, Jabrane-Ferrat N, Peterlin BM: NFkappaB binds P-TEFb to stimulate transcriptional elongation by RNA polymerase II. Mol Cell 2001, 8:327-337.

34. Marks PA, Breslow R: Dimethyl sulfoxide to vorinostat: development of this histone deacetylase inhibitor as an anticancer drug. Nat Biotechnol 2007, 25:84-90.

35. Keedy KS, Archin NM, Gates AT, Espeseth A, Hazuda DJ, Margolis DM: A limited group of class I histone deacetylases acts to repress human immunodeficiency virus type 1 expression. J Virol 2009, 83:4749-4756. 
36. Burnett JC, Lim KI, Calafi A, Rossi JJ, Schaffer DV, Arkin AP: Combinatorial latency reactivation for HIV-1 subtypes and variants. J Virol 2010, 84:5958-5974.

37. Fernandez G, Zeichner SL: Cell line-dependent variability in HIV activation employing DNMT inhibitors. Virol J 2010, 7:266.

38. Reuse S, Calao M, Kabeya K, Guiguen A, Gatot JS, Quivy V, Vanhulle C, Lamine A, Vaira D, Demonte D, Martinelli V, Veithen E, Cherrier T, Avettand V, Poutrel S, Piette J, de Launoit Y, Moutschen M, Burny A, Rouzioux C, de Wit S, Herbein G, Rohr O, Collette Y, Lambotte O, Clumeck N, van Lint C: Synergistic activation of HIV-1 expression by deacetylase inhibitors and prostratin: implications for treatment of latent infection. PLoS One 2009, 4:e6093.

39. Williams SA, Chen LF, Kwon H, Fenard D, Bisgrove D, Verdin E, Greene WC: Prostratin antagonizes HIV latency by activating NF-kappaB. J Biol Chem 2004, 279:42008-42017

40. Williams SA, Chen LF, Kwon H, Ruiz-Jarabo CM, Verdin E, Greene WC: NFkappaB p50 promotes HIV latency through HDAC recruitment and repression of transcriptional initiation. EMBO J 2006, 25:139-149.

41. Yu S, Cui K, Jothi R, Zhao DM, Jing X, Zhao K, Xue HH: GABP controls a critical transcription regulatory module that is essential for maintenance and differentiation of hematopoietic stem/progenitor cells. Blood 2011, 117:2166-2178.

42. Butera ST, Perez VL, Wu BY, Nabel GJ, Folks TM: Oscillation of the human immunodeficiency virus surface receptor is regulated by the state of viral activation in a CD4+ cell model of chronic infection. J Virol 1991 65:4645-4653.

43. Clouse KA, Powell D, Washington I, Poli G, Strebel K, Farrar W, Barstad P, Kovacs J, Fauci AS, Folks TM: Monokine regulation of human immunodeficiency virus- 1 expression in a chronically infected human T cell clone. J Immunol 1989, 142:431-438.

44. Folks TM, Justement J, Kinter A, Dinarello CA, Fauci AS: Cytokine-induced expression of HIV-1 in a chronically infected promonocyte cell line. Science 1987, 238:800-802.

45. Jordan A, Bisgrove D, Verdin E: HIV reproducibly establishes a latent infection after acute infection of T cells in vitro. EMBO J 2003, 22:1868-1877.

46. Alimonti JB, Ball TB, Fowke KR: Mechanisms of CD4+ T lymphocyte cell death in human immunodeficiency virus infection and AIDS. J Gen Virol 2003, 84:1649-1661.

47. Andersen $J$, Le Rouzic E, Planelles V: HIV-1 Vpr: mechanisms of G2 arrest and apoptosis. Exp Mol Pathol 2008, 85:2-10.

48. Althaus $\mathrm{CL}$, De Boer RJ: Intracellular transactivation of HIV can account for the decelerating decay of virus load during drug therapy. Mo/ Syst Biol 2010, 6:348.

49. Singh A, Razooky B, Cox CD, Simpson ML, Weinberger LS: Transcriptional bursting from the HIV-1 promoter is a significant source of stochastic noise in HIV-1 gene expression. Biophys J 2010, 98:L32-L34.

50. Skupsky R, Burnett JC, Foley JE, Schaffer DV, Arkin AP: HIV promoter integration site primarily modulates transcriptional burst size rather than frequency. PLOS Com put Biol 2010, 6.

51. Montano MA, Nixon CP, Ndung'u T, Bussmann H, Novitsky VA, Dickman D, Essex M: Elevated tumor necrosis factor-alpha activation of human immunodeficiency virus type 1 subtype $C$ in Southern Africa is associated with an NF-kappaB enhancer gain-of-function. J In fect Dis 2000, 181:76-81.

52. Roof $P$, Ricci M, Genin $P$, Montano MA, Essex M, Wainberg MA, Gatignol A Hiscott J: Differential regulation of HIV-1 clade-specific B, C, and E long terminal repeats by NF-kappaB and the Tat transactivator. Virology 2002, 296:77-83.

53. Quivy V, Adam E, Collette $Y$, Demonte D, Chariot A, Vanhulle C, Berkhout B, Castellano R, de Launoit Y, Burny A, Piette J, Bours V, van Lint C: Synergistic activation of human immunodeficiency virus type 1 promoter activity by NF-kappaB and inhibitors of deacetylases: potential perspectives for the development of therapeutic strategies. J Virol 2002, 76:11091-11103.

54. Naghavi MH, Schwartz S, Sonnerborg A, Vahlne A: Long terminal repeat promoter/enhancer activity of different subtypes of HIV type 1. AIDS Res Hum Retroviruses 1999, 15:1293-1303.

55. Verhoef K, Sanders RW, Fontaine V, Kitajima S, Berkhout B: Evolution of the human immunodeficiency virus type 1 long terminal repeat promoter by conversion of an NF-kappaB enhancer element into a GABP binding site. J Virol 1999, 73:1331-1340.
56. Smith SD, Shatsky M, Cohen PS, Warnke R, Link MP, Glader BE: Monoclonal antibody and enzymatic profiles of human malignant T-lymphoid cells and derived cell lines. Cancer Res 1984, 44:5657-5660.

57. Peden K, Sheng L, Omeir R, Yacobucci M, Klutch M, Laassri M, Chumakov K, Pal A, Murata $H$, Lewis AM Jr: Recovery of strains of the polyomavirus SV40 from rhesus monkey kidney cells dating from the 1950s to the early 1960s. Virology 2008, 370:63-76.

58. Das AT, Klaver B, Berkhout B: A hairpin structure in the $\mathrm{R}$ region of the human immunodeficiency virus type 1 RNA genome is instrumental in polyadenylation site selection. J Virol 1999, 73:81-91.

59. Ruijter JM, Thygesen HH, Schoneveld OJ, Das AT, Berkhout B, Lamers WH: Factor correction as a tool to eliminate between-session variation in replicate experiments: application to molecular biology and retrovirology. Retrovirology 2006, 3:2.

60. de Baar MP, de Ronde A, Berkhout B, Cornelissen M, van der Horn KH, van der Schoot AM, de Wolf F, Lukashov W, Goudsmit J: Subtype-specific sequence variation of the HIV type 1 long terminal repeat and primerbinding site. AIDS Res Hum Retroviruses 2000, 16:499-504.

61. Abebe A, Pollakis G, Fontanet AL, Fisseha B, Tegbaru B, Kliphuis A, Tesfaye G, Negassa H, Cornelissen M, Goudsmit J, Rinke de Wit TF: Identification of a genetic subcluster of HIV type 1 subtype $C\left(C^{\prime}\right)$ widespread in Ethiopia. AIDS Res Hum Retroviruses 2000, 16:1909-1914.

62. Heeregrave EJ, Geels MJ, Brenchley JM, Baan E, Ambrozak DR, van der Sluis RM, Bennemeer R, Douek DC, Goudsmit J, Pollakis G, Koup RA, Paxton WA: Lack of in vivo compartmentalization among HIV-1 infected naive and memory CD4+ T cell subsets. Virology 2009, 393:24-32.

doi:10.1186/1742-4690-8-73

Cite this article as: van der Sluis et al:: Latency profiles of full length HIV-1 molecular clone variants with a subtype specific promoter. Retrovirology 2011 8:73.

\section{Submit your next manuscript to BioMed Central and take full advantage of:}

- Convenient online submission

- Thorough peer review

- No space constraints or color figure charges

- Immediate publication on acceptance

- Inclusion in PubMed, CAS, Scopus and Google Scholar

- Research which is freely available for redistribution

Submit your manuscript at www.biomedcentral.com/submit
C) Biomed Central 